\title{
High Light Intensity Increases the CAM Expression in "MD-2" Micro-Propagated Pineapple Plants at the End of the Acclimatization Stage
}

\author{
René C. Rodríguez-Escriba1 ${ }^{*}$, Romelio Rodríguez, Dariel López¹, Gustavo Y. Lorente1, \\ Yaima Pino1, Carlos E. Aragón1, Yolanda Garza², Florencio E. Podestá ${ }^{3}$, \\ Justo L. González-Olmedo ${ }^{1}$ \\ ${ }^{1}$ Laboratorio de Agrobiología, Centro de Bioplantas, Universidad de Ciego de Ávila, Ciego de Ávila, Cuba \\ ${ }^{2}$ Departamento Biotecnología, Facultad Ciencias Químicas, Universidad Autónoma de Coahuila, Coahuila, \\ México \\ ${ }^{3}$ Centro de Estudios Fotosintéticos y Bioquímicos, Facultad de Ciencias Bioquímicas y Farmacéuticas, \\ Universidad Nacional de Rosario, Rosario, Argentina \\ Email: *renecarlos@bioplantas.cu
}

Received 15 July 2015; accepted 7 December 2015; published 10 December 2015

Copyright (C) 2015 by authors and Scientific Research Publishing Inc.

This work is licensed under the Creative Commons Attribution International License (CC BY).

http://creativecommons.org/licenses/by/4.0/

(c) (i) Open Access

\section{Abstract}

This work describes the evaluation of morpho-physiological and biochemical changes in "MD-2" micro-propagated pineapple plants (Ananas comosus (L.) Merr.) grown after 30 days under low light intensity (LL, greenhouse light conditions at $250 \mu \mathrm{mol} \cdot \mathrm{m}^{-2} \cdot \mathrm{s}^{-1}$ ) or high light intensity (HL, field light conditions at $800 \mu \mathrm{mol} \cdot \mathrm{m}^{-2} \cdot \mathrm{s}^{-1}$ ). Gas exchange, leaf $\mathrm{pH}$, protein content and superoxide dismutase activity (SOD) (EC 1.15.1.1) were measured every $3 \mathrm{~h}$ during one day. Chlorophylls content and succulence index (SI) were determined at $9 \mathrm{~h}$. Results showed significant differences in $\mathrm{CO}_{2}$ exchange rates, with a maximum occurring at $6 \mathrm{~h}\left(3.00\right.$ and $8.25 \mu \mathrm{mol} \mathrm{CO}_{2} \mathrm{~m}^{-2} \cdot \mathrm{s}^{-1}$ for leaves under LL and HL conditions respectively). Plants under HL conditions had higher $\mathrm{CO}_{2}$ uptake and lower pH values between $0 \mathrm{~h}$ and $6 \mathrm{~h}$ respective to $\mathrm{LL}$ plants. The maximum pH value was attained $3 \mathrm{~h}$ before in HL plants. Leaf SI was increased and chlorophyll content decreased by HL conditions. SOD activity was higher in plants under HL conditions, near doubling those of LL plants at $18 \mathrm{~h}(2.8$ versus $1.5 \mathrm{U} \cdot \mathrm{mg}^{-1}$ Protein respectively). Both groups showed a typical CAM phenotype, but it was stronger in HL conditions, which may confer these plants with a better acclimation to transfer to the field.

\footnotetext{
*Corresponding author.
} 


\section{Keywords}

\section{Crassulacean Acid Metabolism, Hardening Stage, Ex Vitro, Vitroplants, Gaseous Exchange}

\section{Introduction}

Pineapple (Ananascomosus (L.) Merr.) is a perennial monocot plant belonging to the family Bromeliaceae, subfamily Bromelioideae, in the order Bromeliales. Pineapple is one of the most economically important tropical fruits [1] and the most of CAM plants [2]. After bananas and mangoes, it is the third most important tropical fruit produced in the worldwide [1]. Pineapple is propagated vegetatively, using crowns, slips, shoots or suckers, but these planting materials have their limitations including less uniformity, transmission of diseases, and inadequacy for commercial production. In vitro propagation is a crucial technique for disease free, rapid and mass production of pineapple plantlets [3]. In micro-propagation techniques, the pineapple multiplication rate can be considered low and it would take some years to obtain enough propagules [4]. The use of Temporary Immersion System (TIS) techniques can solve this problem, by increasing the number of pineapple plantlets with higher quality produced over short time, as a result of a better handling of the in vitro atmosphere and the nutrition [5]. Large-scale production of in vitro pineapple plantlets started in Cuba in some years ago [6]. After in vitro massive propagation, it is often necessary to adapt plantlets to the harsher and uncontrolled ex vitro environment. This may occur in a greenhouse or field during a phase called acclimatization or hardening [7]. Many authors have studied the factors affecting acclimatization in pineapple, such as light intensity [8], $\mathrm{CO}_{2}$ enrichment, light and relative humidity controlled in in vitro conditions [5], or addition of bioferilizers during this phase [9]. Very often acclimatized plants do not have the appropriate size for direct planting into the field, which results in poor survival after transferral. To attain a better survival rate and establishment on field, these plants need to be further acclimatized in greenhouses using different pots, substrates, fertilizer programs, controlled light intensity and temperature and other important factors until plants reach the appropriate size [10]. Micro-propagated pineapple plants have a plastic morphology and physiology that can change according to the growth conditions. Temperature determines the occurrence of $\mathrm{C}_{3}$ or CAM photosynthesis in pineapple plantlets grown under in vitro conditions [11], this behavior is also modulated by nitric oxide and water availability [12]. Besides $\mathrm{C}_{3}$ or CAM metabolism in pineapple plantlets was conditioned by a combination of low relative humidity, and high temperatures and light intensity during the 4 first weeks of ex vitro growth [13] [14]. It is known that adult macro-propagated pineapple plants are classified like "strong constitutive CAM plants" [15]-[18]. For this reason, we conjecture that micro-propagated pineapple plants don't have the CAM expression degree and the defensive or adaptive mechanisms prepared like naturally grown pineapple plants in their natural habitat. Not much is known about the $\mathrm{C}_{3}$ to CAM metabolism transitions in micro-propagated young pineapples plants, during or at the end of acclimatization phase. The aim of this work was to examine some morphological, physiological and biochemical changes in micro-propagated pineapple, 5-month old plants, grown during thirty days under low or high photosynthetic photon flux, in a greenhouse or under field light conditions respectively.

\section{Materials and Methods}

\subsection{Plant Material and Growth Conditions}

Pineappleplants (Ananascomosus (L.) Merr.) "MD-2” were micro-propagated as described by [19]. Plants were selected from plastic culture vessels according tothe following morphological characteristics: plants around of $4.0 \mathrm{~cm}$ height, 7.0 to $8.0 \mathrm{~g}$ fresh weight (FW), with 5 or 6 leaves on average [3]. Plants were dipped in 3.0 $\mathrm{ml} \cdot \mathrm{L}^{-1}$ of Previcur Energy ${ }^{\circledR}$ (Bayer Crop Science) during $5 \mathrm{~min}$ and planted in plastic $250 \mathrm{~cm}^{3}$ glasses on a mixture of 1:1 (v:v) red ferralytic soil and filter cake (derived from sugarcane bagasse) [10]. Plants were acclimated in a greenhouse during five month under $80 \% \pm 3 \%$ relative humidity, $25.5^{\circ} \mathrm{C} \pm 2{ }^{\circ} \mathrm{C}$ temperature and $250 \pm 25$ $\mu \mathrm{mol} \mathrm{m} \mathrm{s}^{-2} \mathrm{~s}^{-1}$ photosynthetic photon flux (PPF). Irrigation consisted of a 30 minmist at 9:00 am daily. A foliar fertilizer mix containing 16.0 g of crystalline N-P-K plus $1.0 \mathrm{~g}$ of Multimicro Comb (Haifa Chemicals Ltd., Haifa Bay 26,120, Israel) into $16 \mathrm{~L}$ of water was applied every ten days. Five months old plants were divided in two groups and cultivated during 30 days under different environmental conditions differing basically in illumination (Table 1). Fertilization and irrigation was similar to the acclimatization conditions described previously. 
Table 1. Experimental conditions of six month old micro-propagated pineapple plants, measured under greenhouse and field light conditions.

\begin{tabular}{ccccccc}
\hline & \multirow{2}{*}{$\begin{array}{c}\text { PPF }(12 \mathrm{~h}) \\
\text { Growth conditions }\end{array}$} & \multicolumn{2}{c}{ Relative Humidity $(\%)$} & \multicolumn{2}{c}{ Temperature $\left({ }^{\circ} \mathrm{C}\right)$} \\
\cline { 3 - 6 }$\left(\mu \mathrm{mol} \mathrm{m}^{-2} \cdot \mathrm{s}^{-1}\right)$ & & Day & Night & Day & Night \\
\hline Greenhouse light conditions & $250 \pm 30$ & $68 \pm 3$ & $78 \pm 3$ & $33 \pm 2$ & $22 \pm 2$ \\
Field light conditions & $800 \pm 30$ & $71 \pm 3$ & $82 \pm 3$ & $32 \pm 2$ & $25 \pm 2$ \\
PPF-Photosynthetic photon flux. & & & & & \\
\hline
\end{tabular}

All measurements and determinations were carried out at 30din the D-leaf of plants (defined like the tallest leaf on the plant [15]). The experiment was done between September and October of 2013.

\subsection{Methods Used}

Morphological measurements: D-leaf length and weight were taken using a graduate ruler. Leaf water content was determined as the difference between the fresh weight (FW) and the weight after drying for $72 \mathrm{~h}$ at $60^{\circ} \mathrm{C}$ [dry weight (DW)] in the D-leaf of nine plantstaken at $9 \mathrm{~h}$.

Gas exchange measurements: Samples were collected each 3 h during whole day and fifteen determinations were done on six D-leaves of plants for each treatment and day time. Gaseous exchange was quantified using an infrared gas analyzer (PP Systems CIRAS-2 Portable Photosynthesis System) coupled ata universal cuvette: PLC6 (U), $1.7 \mathrm{~cm}^{2}$. $\mathrm{CO}_{2}$ exchange $\left(\mu \mathrm{mol} \mathrm{CO} \mathrm{Cm}^{-2} \cdot \mathrm{s}^{-1}\right)$ and transpiration rates $\left(\mathrm{mmol} \mathrm{H} \mathrm{H}_{2} \mathrm{O} \mathrm{m}{ }^{-2} \cdot \mathrm{s}^{-1}\right)$ were measured underphotosynthetic photon flux of $600 \mu \mathrm{mol} \mathrm{m} \mathrm{m}^{-2} \cdot \mathrm{s}^{-1}$. CIRAS-2 was automatically calibrated before each measurement. Water-use efficiency (WUE) was calculated as ratio between $\mathrm{CO}_{2}$ exchange and transpiration rates and defined as amount $\mu$ mol $\mathrm{CO}_{2}$ exchange per mmol $\mathrm{H}_{2} \mathrm{O}$ transpired $\left(\mu \mathrm{mol} \mathrm{CO} \mathrm{Cmol}^{-1} \mathrm{H}_{2} \mathrm{O}\right)$.

Chlorophyll content determination: Samples of three D-leaves were collected at $9 \mathrm{~h}$, and stored under liquid nitrogen until each determinations were made. Samples $(0.1 \mathrm{~g})$ were ground to a fine powder using liquid nitrogen with a pestle and mortar. The powder was diluted into $500 \mu \mathrm{l}$ of $2.5 \mathrm{mM}$ potassium phosphate- $\mathrm{KOH} / 80 \%$ acetone, $\mathrm{pH} 7.8$, and centrifuged at $12,000 \mathrm{~g}$ during $5 \mathrm{~min}$ at $4^{\circ} \mathrm{C}$. The supernatant was used for spectrophotometric determination. Chlorophyll concentration was calculated by the equations described by Porra (2002) [20], using a Pharmacia Bio-spectrophotometer. Chlorophyll contents were expressed as $\mu \mathrm{g} \cdot \mathrm{g}^{-1} \mathrm{FW}$.

Leaves pH determination: Six fresh D-leaves of plants were collected every $3 \mathrm{~h}$ for $24 \mathrm{~h}$. Samples were crushed and $0.5 \mathrm{ml}$ of the resulting fluid were collected, clarified by addition of activated charcoal and centrifuged at 12,000 g during 5 min. Supernatant $\mathrm{pH}$ was immediately quantified with $\mathrm{pH}$ indicator strips (Merck KGaA 64,271) according to Aragón et al. (2012) [13].

Succulence index (SI): The succulence index was calculated using the values of chlorophyll content, fresh weight (FW) and dry weight (DW) to calculate in the formula: SI $=(\mathrm{FW}-\mathrm{DW})[\mathrm{Chl}(a+b)]^{-1}[21]$.

Extraction and quantification of proteins and SOD assay: Six D-leaf were collected every $3 \mathrm{~h}$ for $24 \mathrm{~h}$ and stored under liquid nitrogen until each determinations were made. Frozen samples were ground into a fine powder using liquid nitrogen. FW-buffer ratio was $0.25 \mathrm{~g}$ into $2 \mathrm{~mL}$ of extraction buffer containing $50 \mathrm{mM}$ potassium phosphate $\mathrm{pH}$ 7.8, 1 mM EDTA, 1\% (v/v) Triton X-100, 1\% (w/v) polyvinyl-pyrrolidone (PVP), 1 mM dithiothreitol (DTT) and $1 \mathrm{mM}$ phenyl-methylsulfonyl fluoride (PMSF). The resulting material was centrifuged at 15,000 g during $20 \mathrm{~min}$ at $4^{\circ} \mathrm{C}$ and the soluble fraction was collected for SOD (EC 1.15.1.1) activity determination. Total soluble proteins were determined according to Bradford, (1976) [22], using as reference Bovine seroalbumin (BSA). SOD was assayed by the ferricytochrome $\mathrm{C}$ method, using xanthine/xanthine oxidase as the source of superoxide radicals [23], in $1 \mathrm{~mL}$ of a reaction mixture containing $50 \mathrm{mM}$ potassium phosphate-KOH buffer $\mathrm{pH}$ 7.6, $0.1 \mathrm{mM}$ EDTA, $0.01 \mathrm{mM}$ cytochrome C, $0.05 \mathrm{mM}$ xanthine, 0.03 units xanthine oxidase (EC 1.1.3.22, Sigma Aldrich) and the soluble crude extract $(80 \mu \mathrm{L})$. All measurements were made using a Pharmacia Bio-spectrophotometer, and one SOD unit was defined as the enzyme amount which caused $50 \%$ inhibition of the initial rate of reduction of cytochrome C.

Statistical analysis: The experiment was conformed in completely random blocks. At each sampling time and treatment, six plants were randomly selected to measure of gas exchange (with fifteen measurements to each one) and for determination of leaf $\mathrm{pH}$ and SOD activity (with two repetition to each one), nine samples for fresh 
and dry weight, thirty for length and width of D-leaf, and six (with two repetition to each one) for chlorophyll content determinations. All analysis statistical analyses were carried out using SPSS version 12 [24]. Statistical significance was assessed where indicated through two-way analysis of variance (ANOVA) followed by Tukey’s Multiple Range Test for bi-factorials comparisons or Student's t-test for comparison of two conditions, both at $5 \%$ significance level.

\section{Results \& Discussion}

\subsection{Morphological Changes}

Pineapple plants grown under HL conditions increased the D-leaf width at thirty days, while D-leaf length did not show significant differences (Table 2). In vitro cultured pineapple leaves are longer and narrower than pineapple macro-propagated plants, which could be related to the low light of the culture room [13]. D-leaf width increment, could be a response to high light intensity conditions, also it is know that the D-leaf width of micro-propagated pineapple plants was increased to $3.5 \mathrm{~cm}$ at 60 days of planted in field [6]. Plants under HL conditions every 30 days increased the fresh and dry weight including water content of D-leaf. The succulent leaf and stem of CAM plants have very high water-storage capacitance in their above-ground tissues [2]. In different CAM plants formation of water storage tissues could be observed after exposure to high light intensity, perhaps as a heat dissipation strategy [13], this could be the answer to differences between both groups, which could be related to synthesis of water-storage tissues being higher in plants under HL conditions.

\subsection{Gas Exchange}

Night $\mathrm{CO}_{2}$ fixation is initiated by phosphoenolpyruvate carboxylase (PEPC) (E.C. 4.1.1.3 l), in a light-independent way, whereas daytime assimilation is light-dependent and fixed by ribulose-l.5-bisphosphate carboxylase-oxygenase (RubisCO) (EC 4.1.1.39). The distinctive pattern of $\mathrm{CO}_{2}$ exchange (Figure $1(\mathrm{~A})$ ) and transpiration rate (Figure $1(B)$ ), are consistent with a well-established CAM mode. $\mathrm{Net} \mathrm{CO}_{2}$ uptake was occurred predominantly at night, while daytime $\mathrm{CO}_{2}$ exchange at $15 \mathrm{~h}$ and $18 \mathrm{~h}$ was substantially negative in both groups (Figure 1(A)). CAM-functioning of micro-propagated pineapple plants is intrinsically related to the expression of PEPC coding genes [14]. Besides PEPC activity in CAM plants is controlled by a phosphorylation-dephosphorylation process by phosphoenolpiruvate carboxylase-kinase (PPCK) in which the phosphorylated enzyme, that abounds during the night period, is less susceptible to inhibition by malate and more responsive to the allosteric activator glucose-6-phosphate (Glc-6-P) [25]. The maximum $\mathrm{CO}_{2}$ exchange rate was recorded at $6 \mathrm{~h}$ in both groups, although in plants under LL conditions it was significantly lower than in the HL treatment (Figure $1(\mathrm{~A})$ ). The $\mathrm{CO}_{2}$ exchange rate at $6 \mathrm{~h}\left(8.25\right.$ and $\left.3.0 \mu \mathrm{mol} \mathrm{CO} \mathrm{Cm}^{-2} \cdot \mathrm{s}^{-1}\right)$ show that HL plants fixed approximately $64 \%$ more $\mathrm{CO}_{2}$ than plants under LL conditions. CAM plants immediately after dawn (phase II) can increase $\mathrm{CO}_{2}$ uptake, since both carboxylating enzymes (Rubis CO and PEPC) are active [26]. Light saturation (photon photosynthetic flux) of pineapple plants occur at about $500 \mu \mathrm{mol} \cdot \mathrm{m}^{-2} \cdot \mathrm{s}^{-1}[13]$. However for plants grown under greenhouse, PPF was about to $250 \mu \mathrm{mol} \cdot \mathrm{m}^{-2} \cdot \mathrm{s}^{-1}$ at $12 \mathrm{~h}$, and much lower than that $6 \mathrm{~h}$. This could account for the observed differences y maximum $\mathrm{CO}_{2}$ uptake at this time. The observed values could also be the result of less PEPC activity due to lower expression under low light. This could also explain that plants under HL conditions increased their D-leaf dry weight (Table 2), since better $\mathrm{CO}_{2}$ uptake means more substrate available for anabolic processes such as tissue growth. In CAM plants, phases II and IV (dawn and

Table 2. Morphological characteristics of D-leaf of six month old micro-propagated pineapple plants grown during thirty days under greenhouse light conditions $\left(\mathrm{PPF}=250 \mu \mathrm{mol} \cdot \mathrm{m}^{-2} \cdot \mathrm{s}^{-1}\right)$ and field light conditions $\left(\mathrm{PPF}=800 \mu \mathrm{mol} \cdot \mathrm{m}^{-2} \cdot \mathrm{s}^{-1}\right)$.

\begin{tabular}{|c|c|c|c|c|c|}
\hline Growth conditions & Length (cm) & Width (cm) & FW (g) & DW (g) & WC (g) \\
\hline Greenhouse light conditions & 21.67 a & $2.50 \mathrm{~b}$ & $25.23 \mathrm{~b}$ & $2.28 \mathrm{~b}$ & $22.95 \mathrm{~b}$ \\
\hline Field light conditions & $21.59 \mathrm{a}$ & $2.83 \mathrm{a}$ & $27.35 \mathrm{a}$ & $2.51 \mathrm{a}$ & $24.84 \mathrm{a}$ \\
\hline SE & 0.38 & 0.15 & 0.95 & 0.12 & 0.84 \\
\hline
\end{tabular}

PPF—Photosynthetic photon flux, FW—-fresh weight; DW—dry weight, WC—water content, SE—mean's standard error. Different letters indicate significant statistical differences after Student's t-test $p<0.05$. Data represent means to $\mathrm{n}=9$ in case of FW, DW and WC, and $\mathrm{n}=30$ for D-leaf length and width. 


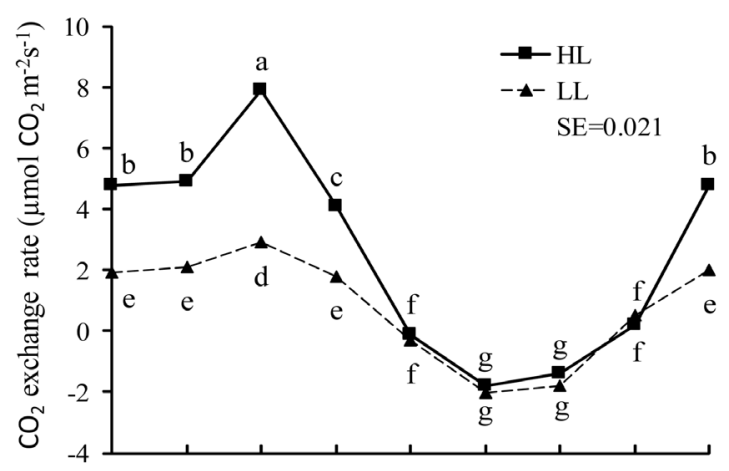

(A)

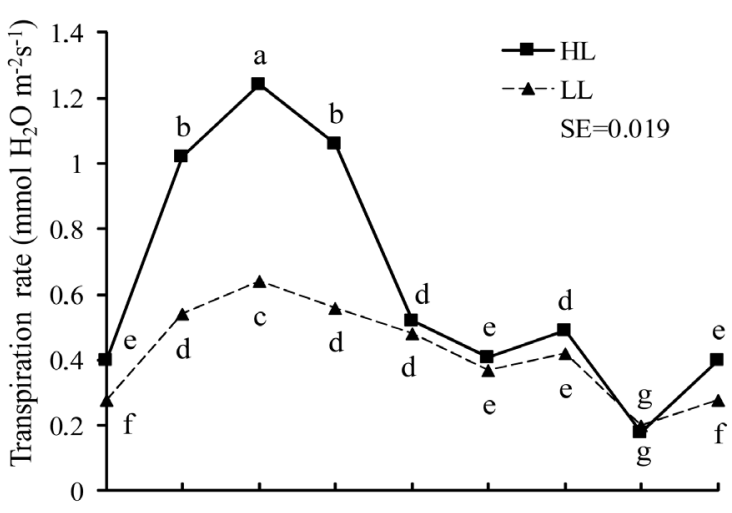

(B)

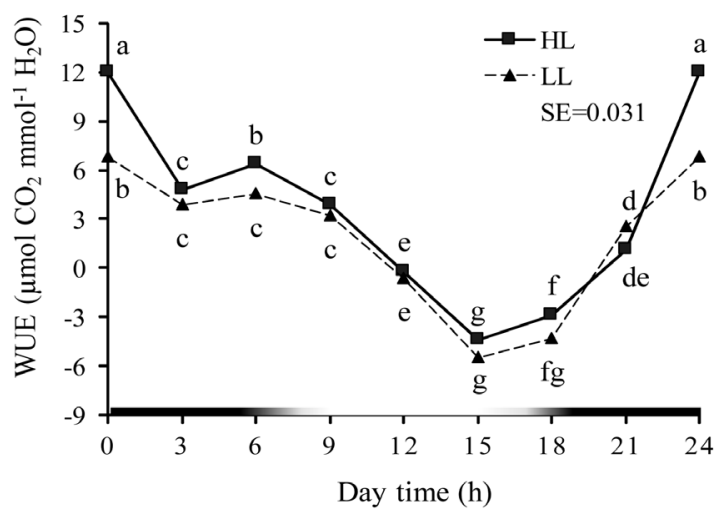

(C)

Figure 1. $\mathrm{CO}_{2}$ exchange rate (A) Transpiration rate (B) and water-use efficiency (WUE) (C) in leaves of six month old micro-propagated pineapple plants (Ananascomosus (L.) Merr.) "MD-2" grown during thirty days under greenhouse light conditions (low light intensity (LL), with a photosynthetic photon flux, PPF $=250 \mu \mathrm{mol} \cdot \mathrm{m}^{-2} \cdot \mathrm{s}^{-1}$ ) and field light conditions (high light intensity (HL), PPF $=800 \mu \mathrm{mol} \cdot \mathrm{m}^{-2} \cdot \mathrm{s}^{-1}$ ). Data are the mean of six plants and fifteen measures to each one. The values recorded at $0 \mathrm{~h}$ and $24 \mathrm{~h}$ were idem. Different letters indicate significant statistical differences after two-way ANOVA, Tukey's test, $p<0.05$ to $\mathrm{n}=90$. SE-mean's standard error. The section black on $\mathrm{x}$-axis bar denotes the hours of time night.

nightfall, respectively) are often recognized like phases in which the $\mathrm{CO}_{2}$ uptake via RubisCO (C3) and PEPC (C4) simultaneously is decisive for growth [26]. Co-ordination of carboxylases is essential for the efficient functioning of the CAM pathway, phase II is often characterized by a period of atmospheric $\mathrm{CO}_{2}$ uptake which largely appear to be dominated by PEPC, while RubisCO remain at a low activation state until PEPC is dephosphorylated [27].

Transpiration rates in leaves of plants grown under HL conditions were significantly higher between 0 h and 9 h compared with plants in LL (Figure 1(B)). From $6 \mathrm{~h}$ on, transpiration rate declined steadily in both treatments to dawn without significant differences. Normally, light can induce stomatal opening, although for CAM species this happens at night [28]. This shows that under both treatment CAM is functioning, however, adult and macro-propagated pineapple plants shown a different behavior according to gasexchange patterns [15] [16] [18]. In fact pineapple is classified like a strong, constitutive CAM specie under field conditions, but micro-propagated pineapple plants can show the $\mathrm{C}_{3}$ mode of photosynthesis [11] [12]. Stomatal re-opening of leaves in both treatments to allow significant night gas exchange after $21 \mathrm{~h}$ is also an indication of CAM functioning (Figure 1(B)).

Gas exchange-efficiency result was shown in Figure $1(\mathrm{C})$. At $0 \mathrm{~h}$ and $6 \mathrm{~h}$ HL plants showed the highest WUE values with statistical differences compared with LL. It is known that an increase in WUE is an adaptive response of CAM plants terrestrials [29]. Both groups showed a similar water efficiency during the daily cycle, but plants under HL conditions were more efficient at $0 \mathrm{~h}$ and $6 \mathrm{~h}$. On the other hand, between $12 \mathrm{~h}$ and $18 \mathrm{~h}$ WUE was substantially negative, which can be related to stomatal closure during day (phase III), where metabolic balance are inclined to respiratory processes, which is supported by negative values of $\mathrm{CO}_{2}$ exchange during the same hours (Figure 1(C)). 


\subsection{Chlorophylls Content and Succulence Index}

Leaves of pineapple plants grown in LL contained more chlorophyll $(a, b$ and $a+b)$, than plant leaves under HL conditions (Table 3). The chlorophyll $a / b$ ratio did not show significant differences. Leaf chlorophyll content was affected by long-term high light exposition. The higher chlorophyll content in plants leaves under HL conditions during thirty days is an indicative of better acclimation to sun conditions. Higher values of total chlorophyll without a concomitant decrease in chlorophyll $a / b$ ratio during acclimation of photosynthetic tissue to lower light levels, will occur if there is an increase in the number, but not size, of the "photosynthetic units" (PSU) in the tissue, as increases in PSU size in response to lower light levels typically reflect, in particular, an increase in the light-harvesting portions of the photosynthetic pigment/protein complex in both photo systems [30]. Also it can explain that pineapple plants under HL and LL conditions showed similar chlorophylls $a / b$ ratio. Chloroplasts in leaves developing in the shade tend to have more photosynthetic pigments per unit volume, more thylakoids, a greater relative stacking of thylakoids into grana, and therefore a greater light-absorbing ability than do chloroplasts developing under high illumination [31]. Pineapple plants under HL condition, should be more acclimated to field condition, and should have better mechanisms to light uptake, to support the high energetic cost during phase III, which are required in the decarboxylation process during daytime [26]. SI values were significantly higher in plants grown in HL (Table 3). A clear difference is evident between treatments, which is the result of different degrees of CAM expression. The magnitude of CAM induction in facultative CAM plants tends not only to be influenced by water deficit, but also by associated environmental conditions such as temperature, light intensity, and humidity [29]. It is well established that high light intensity could enhance CAM.

\subsection{Leaf $\mathrm{pH}$}

The D-leaf $\mathrm{pH}$ was measured in leaves of plants under LL or HL at the same time points, during the day and night periods (Figure 2). The $\mathrm{pH}$ values started to rise in the early morning (9 h, starting at $\mathrm{pH}$ 3.0) in HL plants but only at $12 \mathrm{~h}$ (starting at $\mathrm{pH} 4.0$ ) in LL, respectively. In both treatments there is a clear trend of nocturnal acidification versus daytime deacidification, typical of CAM. However, the degree of acidification and the time frame in which it changes are clearly different among treatments. The leaf $\mathrm{pH}$ of LL plants was high compared to HL plants at all times during the night period. This should be related toa better CAM expression, which is also supported by results of $\mathrm{CO}_{2}$ exchange during the same time (Figure 1(A)). Organic acid levels-changes in pineapple plants is due fundamentally to changes of malic acid levels [32]. The lower $\mathrm{pH}$ levels of plants under HL can be related to a higher amount of malic acid (perhaps the result of higher PEPC levels/activity). LL plants started to deacidify $3 \mathrm{~h}$ later than those under HL conditions, although in both cases an identical maximum $\mathrm{pH}$ was attained. While it is evident that greenhouse conditions affect the behavior of CAM, the reason behind this effect is not clear at present. It could be related to low light intensity, because in CAM plants it has generally been demonstrated that day-time integrated PPF is positively correlated with the magnitude of nocturnal malic acid accumulation and its subsequent mobilization from the vacuole during the following day [33]. Also it may well be that milder conditions affect the tonoplast in such a way that malate efflux is delayed, and with it the whole deacidification process. This would not be unusual given that the tonoplast is probably the master switch governing acid fluctuations in CAM plants as well explained by Lüttge (2000) [34].

Table 3. Changes in chlorophyll content and succulence index in D-leaf of six month old micro-propagated pineapple plants grown during thirty days under greenhouse light conditions $\left(\mathrm{PPF}=250 \mu \mathrm{mol} \cdot \mathrm{m}^{-2} \cdot \mathrm{s}^{-1}\right)$ and field light conditions $(\mathrm{PPF}=800$ $\left.\mu \mathrm{mol} \cdot \mathrm{m}^{-2} \cdot \mathrm{s}^{-1}\right)$.

\begin{tabular}{|c|c|c|c|c|c|}
\hline \multirow{2}{*}{ Growth conditions } & \multicolumn{3}{|c|}{ Chlorophyll $\left(\mu \mathrm{g} \cdot \mathrm{g}^{-1} \mathrm{FW}\right)$} & \multirow{2}{*}{ Chl. $(a / b)$} & \multirow{2}{*}{$\begin{array}{l}\text { Succulence index } \\
\text { (g H } \mathrm{H}_{2} \mathrm{O} \mathrm{mg}{ }^{-1} \mathrm{Chl} \text {.) }\end{array}$} \\
\hline & Chl.a & Chl.b & Chl. $(a+b)$ & & \\
\hline Greenhouse light conditions & 18.57 a & $10.31 \mathrm{a}$ & 28.89 a & $1.80 \mathrm{a}$ & $3.4 \mathrm{~b}$ \\
\hline Field light conditions & $12.23 \mathrm{~b}$ & $7.03 \mathrm{~b}$ & $19.26 \mathrm{~b}$ & $1.78 \mathrm{a}$ & $5.2 \mathrm{a}$ \\
\hline SE & 0.52 & 0.29 & 0.81 & 0.021 & 0.53 \\
\hline
\end{tabular}

PPF-Photosynthetic photon flux, Chl.—Chlorophyll, SE-mean's standard error. Different letters indicate significant statistical differences after Student's t-test $p<0.05$. Data represent means to $\mathrm{n}=12$ in all cases. 


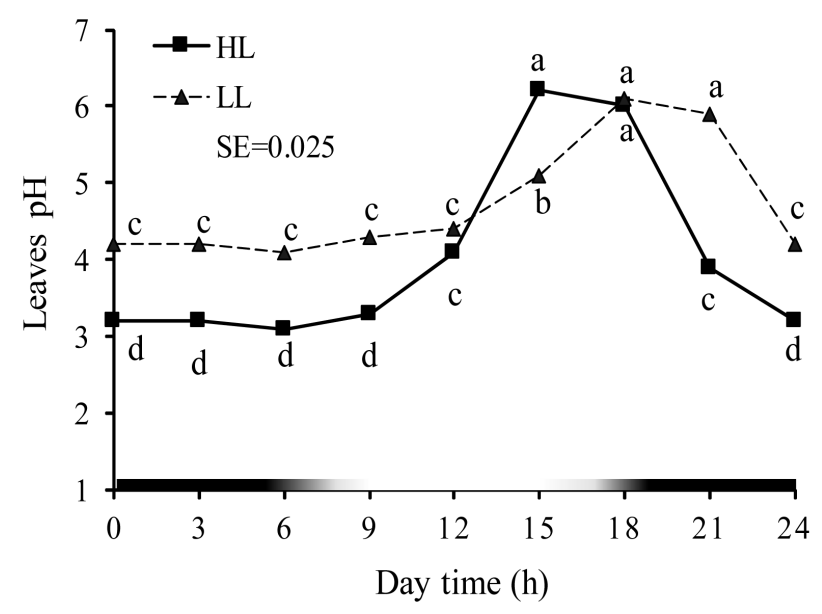

Figure 2. Leaves $\mathrm{pH}$ values in leaves of six month age micro-propagated pineapple plants (Ananascomosus (L.) Merr.) "MD-2" grown during thirty days under greenhouse light conditions (low light intensity (LL), with a photosynthetic photon flux, $\mathrm{PPF}=250 \mu \mathrm{mol} \cdot \mathrm{m}^{-2} \cdot \mathrm{s}^{-1}$ ) and field light conditions (high light intensity (HL), PPF $=800 \mu \mathrm{mol} \cdot \mathrm{m}^{-2} \cdot \mathrm{s}^{-1}$ ). Data are the mean of six plants and two measures to each one. The values obtained at $0 \mathrm{~h}$ and $24 \mathrm{~h}$ were idem. Different letters indicate significant statistical differences after two-way ANOVA, Tukey's test, $p<0.05$ to $\mathrm{n}=12$. SE-mean's standard error. The section black on $\mathrm{x}$-axis bar denotes the hours of time night.

\subsection{SOD Activity}

The high light intensity caused an over production of the Reactive Oxygen Species (ROS), suggested by the daily fluctuation in extractable SOD activity (Figure 3). SOD is one of the primary enzymatic components of the antioxidant system, which converts superoxide into $\mathrm{H}_{2} \mathrm{O}_{2}$ and oxygen, it acts like the first defensive response of enzymatic and non-enzymatic mechanisms into cell to remove ROS. Since ROS formation is extremely difficult to measure, the response of antioxidant system in plants is often used as a marker for ROS production [35] In vitro pineapple plants under stressing environmental conditions presented an oxidative stress pattern of response described by protein damage, altered enzymatic activities (SOD) and gene expression levels, strongly influenced by C3 or CAM-stressing conditions induction [14]. During Phase III of CAM plants the stomata are closed, which can lead to a parallel increase in both the intercellular partial pressure of $\mathrm{O}_{2}\left(\mathrm{piO}_{2}\right)$ and $\mathrm{CO}_{2}$ (pi$\mathrm{CO}_{2}$ ). An increased $\mathrm{O}_{2}$ level in Phase III behind closed stomata can promote overproduction of $\mathrm{H}_{2} \mathrm{O}_{2} / \mathrm{ROS}$ in CAM plants [30]. SOD activity in pineapple plants studied in this work showed a treatment-dependent response. Plants under HL always contained more SOD activity than those under LL, with a minimum ratio HL/LL of 1.25 at $12 \mathrm{~h}$ and 1.7 at $15 \mathrm{~h}$ (Figure 3). This difference is mainly due to the fact the HL plants show an unmistakable time-dependent profile that is only slightly paralleled by LL plants. This finding is in line with the above discussion that suggests that a stronger CAM promotes a stronger ROS generation with associated strong antioxidative response. In that sense LL plants did not produce much ROS and SOD activity was lower. If so, HL plants should be more resistant to oxidative stress and hence able to better cope with an aggressive environment.

\section{Conclusion}

CAM in pineapple plants from in vitro culture was stronger a natural environment (sun) than under greenhouse conditions (shade). The main differences could be related to an increase of CAM expression degree of plants under HL conditions. We argue that these results will expand our knowledge about micro-propagated pineapple plants on new ways to prepare pineapple plants during acclimatization-field transition, and at the same time open new investigations to study the biochemical and molecular mechanisms related with the photosynthetic pathways and oxidative stress in micro-propagated pineapple plants during hardening stage. Considering that micro-propagated pineapple plants could have different behaviors related to $\mathrm{CO}_{2}$ uptake and greatest metabolic plasticity $\left(\mathrm{C}_{3}\right.$ or $\left.\mathrm{CAM}\right)$, depending of both, physiological age and environmental conditions, we can conjectured that CAM degree expression on micro-propagated pineapple plants could be also modulated by other environmental factors, not only at the end of acclimatization stage rather also during it. 


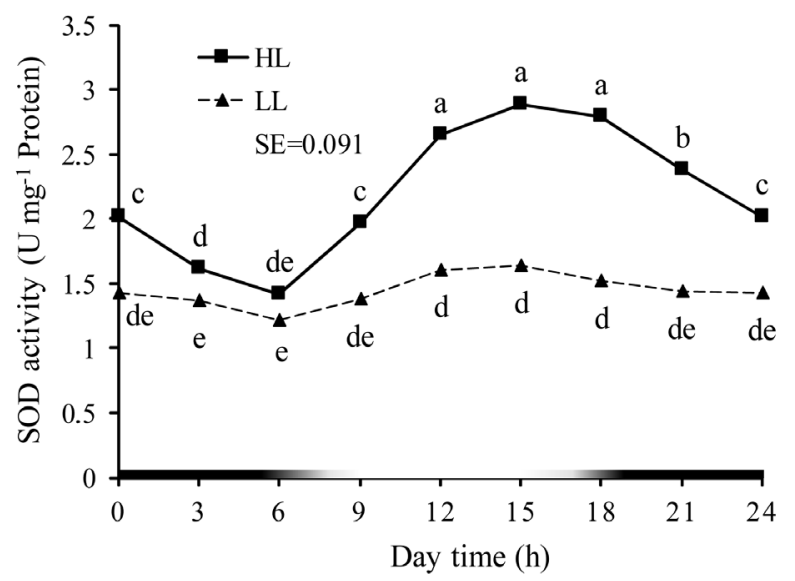

Figure 3. Specific enzymatic activity of Superoxide dismutase (SOD) (EC 1.15.1.1) in leaves of six month old micro-propagated pineapple plants (Ananascomosus (L.) Merr.) "MD-2" grown during thirty days under greenhouse light conditions (low light intensity (LL), with a photosynthetic photon flux, $\mathrm{PPF}=250 \mu \mathrm{mol} \cdot \mathrm{m}^{-2} \cdot \mathrm{s}^{-1}$ ) and field light conditions (high light intensity (HL), PPF $=800 \mu \mathrm{mol} \cdot \mathrm{m}^{-2} \cdot \mathrm{s}^{-1}$ ). Data are the mean of six plants and two measures to each one. The values obtained at $0 \mathrm{~h}$ and $24 \mathrm{~h}$ were idem. Different letters indicate significant statistical differences after two-way ANOVA, Tukey's test, $p$ $<0.05$ to $\mathrm{n}=12$ and mean's standard error (SE). The section black on $\mathrm{x}$-axis bar denotes the hours of time night.

\section{Acknowledgements}

This work was supported by the Endogenous Development Project between Republic of Cuba and the Bolivarian Republic of Venezuela (ALBA contest) and the Pablo Neruda Program, through the Red Iberoamericana de Biotecnología Isla Negra (Isla NegraIbero-American Network of Biotechnology, RIABIN). FEP acknowledges support of ANPCyT (PICT 2011 01122) and CONICET (PIP 0439).

\section{References}

[1] FAOSTAT (2013) Food and Agriculture Organization of the United Stated Nations (FAOSTAT). Helping to Build a World without Hunger. http://faostat3.fao.org/

[2] Borland, A.M., Griffiths, H., Hartwell, J. and Smith, J.A. (2009) Exploiting the Potential of Plants with Crassulacean Acid Metabolism for Bioenergy Production on Marginal Lands. Journal of Experimental Botany, 60, 2879-2896. http://www.ncbi.nlm.nih.gov/pubmed/19395392 http://dx.doi.org/10.1093/jxb/erp118

[3] Escalona, M., Samson, G., Borroto, C. and Desjardins, Y. (2003) Physiology of Effects of Temporary Immersion Bioreactors on Micropropagated Pineapple Plantlets. In Vitro Cellular \& Developmental Biology-Plant, 39, 651-656. http://dx.doi.org/10.1079/IVP2003473

[4] Almeida, W.A.B., Santana, G.S., Rodriguez, A.P.M. and Costa, M.A.P.C. (2002) Optimization of a Protocol for the Micropropagation of Pineapple. Revista Brasileira de Fruticultura, 24, 296-300. http://ref.scielo.org/9s3jcj http://dx.doi.org/10.1590/S0100-29452002000200005

[5] González-Olmedo, J.L., Fundora, Z., Molina, L.A., Abdulnour, J., Desjardins, Y. and Escalona, M. (2005) New Contributions to Propagation of Pineapple (Ananas comosus (L.) Merr.) in Temporary Immersion Bioreactors. In Vitro Cellular \& Developmental Biology-Plant, 41, 87-90. http://dx.doi.org/10.1079/IVP2004603

[6] Rodríguez, R., Becquer, R., Pino, Y., Rodríguez-Escriba, R.C. and López, D. (2013) Introduction of Pineapple Vitroplantas to Field Conditions in Collaboration with Farmers. Preliminary Results. Newsletter of the Pineapple Working Group, International Society for Horticultural Science, 20, 51-56.

[7] Rodriguez, R., Aragon, C.E., Escalona, M., Gonzalez-Olmedo, J.L. and Desjardins, Y. (2008) Carbon Metabolism in Leaves of Micropropagated Sugarcane during Acclimatization Phase. In Vitro Cellular \& Developmental BiologyPlant, 44, 533-539. http://dx.doi.org/10.1007/s11627-008-9142-1

[8] Yanes, E., González-Olmedo, J.L. and Rodríguez, R. (2000) A Technology of Acclimatization of Pineapple Vitroplants. Newsletter of the Pineapple Working Group, International Society for Horticultural Science, 15, 24-35.

[9] Gonzalez-Olmedo, J.L., Coll, F. and Nuñez, M. (2005) A Role for Brassinosteroids during Acclimatization of Pineapple Plantlets. Newsletter of the Pineapple Working Group, International Society for Horticultural Science, 12, 17-20.

[10] Villalobos, A., González, J., Santos, R. and Rodríguez, R. (2012) Morpho-Physiological Changes in Pineapple Plan- 
tlets [Ananas comosus (L.) merr.] during Acclimatization. Ciência e Agrotecnologia, 36, 624-630.

http://ref.scielo.org/s7dgk5

http://dx.doi.org/10.1590/S1413-70542012000600004

[11] Nievola, C.C., Kraus, J.E., Freschi, L., Sousa, B.M. and Mercier, H. (2005) Temperature Determines the Occurrence of CAM or C3 Photosynthesis in Pineapple Plantlets Grown in Vitro. In Vitro Cellular \& Developmental Biology-Plant, 41, 832-837. http://dx.doi.org/10.1079/IVP2005694

[12] Freschi, L., Rodrigues, M.A., Domingues, D.S., Purgatto, E., Van Sluys, M.A., Magalhaes, J.R., Kaiser, W.M. and Mercier, H. (2010) Nitric Oxide Mediates the Hormonal Control of Crassulacean Acid Metabolism Expression in Young Pineapple Plants. Plant Physiology, 152, 1971-1985. http://www.ncbi.nlm.nih.gov/pubmed/20147491 http://dx.doi.org/10.1104/pp.109.151613

[13] Aragón, C., Carvalho, L., González-Olmedo, J.L., Escalona, M. and Amancio, S. (2012) The Physiology of ex Vitro Pineapple (Ananas comosus (L.) Merr. var MD-2) as CAM or C3 Is Regulated by the Environmental Conditions. Plant Cell Report, 31, 757-769. http://www.ncbi.nlm.nih.gov/pubmed/22134875 http://dx.doi.org/10.1007/s00299-011-1195-7

[14] Aragón, C., Pascual, P., González-Olmedo, J.L., Escalona, M., Carvalho, L. and Amancio, S. (2013) The Physiology of ex Vitro Pineapple (Ananas comosus (L.) Merr. var MD-2) as CAM or C3 Is Regulated by the Environmental Conditions: Proteomic and Transcriptomic Profiles. Plant Cell Report, 32, 1807-1818.

http://www.ncbi.nlm.nih.gov/pubmed/23959598 http://dx.doi.org/10.1007/s00299-013-1493-3

[15] Bartholomew, D.P., Paul, R. and Rohrbach, K. (2003) The Pineapple. Botany, Production and Uses. CABI, Wallingford. http://dx.doi.org/10.1079/9780851995038.0000

[16] Nelson, E.A. and Sage, R.F. (2008) Functional Constraints of CAM Leaf Anatomy: Tight Cell Packing Is Associated with Increased CAM Function across a Gradient of CAM Expression. Journal of Experimental Botany, 59, 1841-1850. http://jxb.oxfordjournals.org/content/59/7/1841.abstract http://dx.doi.org/10.1093/jxb/erm346

[17] Lüttge, U. (2010) Ability of Crassulacean Acid Metabolism Plants to Overcome Interacting Stresses in Tropical Environments. AoB Plants, 2010, 1-9. http://www.ncbi.nlm.nih.gov/pubmed/22476063 http://dx.doi.org/10.1093/aobpla/plq005

[18] Prigge, M. and Guriérrez-Soto, M.V. (2014) Pineapple Photosynthesis and Leaf Sap pH as a Surrogate of CAM Performance in the Field. A Research Advance. Newsletter of the Pineapple Working Group, International Society for Horticultural Science, 21, 18-23.

[19] Escalona, M., Lorenzo, J.C., González, B., Daquinta, M., González, J.L., Desjardins, Y. and Borroto, C.G. (1999) Pineapple (Ananas comusus L. Merr) Micropropagation in Temporary Immersion Systems. Plant Cell Report, 18, 743748. http://dx.doi.org/10.1007/s002990050653

[20] Porra, R.J. (2002) The Chequered History of the Development and Use of Simultaneous Equations for the Accurate Determination of Chlorophylls $a$ and $b$. Photosynthesis Research, 73, 149-156. http://dx.doi.org/10.1023/A:1020470224740

[21] Herrera, A. (2009) Crassulacean Acid Metabolism and Fitness under Water Deficit Stress: If Not for Carbon Gain, What Is Facultative CAM Good for? Annals of Botany, 103, 645-653. http://www.ncbi.nlm.nih.gov/pubmed/18708641 http://dx.doi.org/10.1093/aob/mcn145

[22] Bradford, M. (1976) A Rapid and Sensitive Method for the Quantification of Microgram Quantities of Protein Utilizing the Principle of Protein Dye Binding. Analytical Biochemistry, 72, 248-254. http://dx.doi.org/10.1016/0003-2697(76)90527-3

[23] McCord, J.M. and Fridovich, I. (1969) Superoxide Dismutase: An Enzymic Function for Erythrocuprein (Hemocuprein). Journal of Biological Chemistry, 244, 6049-6055. http://www.jbc.org/content/244/22/6049.abstract

[24] Pérez, C. (2005) Técnicas estadísticas con SPSS 12. Aplicaciones al análisis de datos. Pearson Educación, Madrid.

[25] Cushman, J.C. and Bohnert, H.J. (1999) Crassulacean Acid Metabolism: Molecular Genetics. Annual Review of Plant Biology, 50, 305-332. http://www.ncbi.nlm.nih.gov/pubmed/15012212 http://dx.doi.org/10.1146/annurev.arplant.50.1.305

[26] Wild, B., Wanek, W., Postl, W. and Richter, A. (2010) Contribution of Carbon Fixed by RubisCO and PEPC to Phloem Export in the Crassulacean Acid Metabolism Plant Kalanchoe daigremontiana. Journal of Experimental Botany, 61, 1375-1383. http://www.ncbi.nlm.nih.gov/pubmed/20159885 http://dx.doi.org/10.1093/jxb/erq006

[27] Dodd, A.N., Borland, A.M., Haslam, R.P., Griffiths, H. and Maxwell, K. (2002) Crassulacean Acid Metabolism: Plastic, Fantastic. Journal of Experimental Botany, 53, 569-580. http://www.ncbi.nlm.nih.gov/pubmed/11886877 
http://dx.doi.org/10.1093/jexbot/53.369.569

[28] Kluge, M. and Ting, I. (1978) Crassulacean Acid Metabolism: Analysis of an Ecological Adaptation. Springer-Verlag, Berlin. http://dx.doi.org/10.1007/978-3-642-67038-1

[29] Lüttge, U. (2004) Ecophysiology of Crassulacean Acid Metabolism (CAM). Annals of Botany, 93, 629-652. http://www.ncbi.nlm.nih.gov/pubmed/15150072 http://dx.doi.org/10.1093/aob/mch087

[30] Jia, H., Liggins, J.R. and Chow, W.S. (2012) Acclimation of Leaves to Low Light Produces Large Grana: The Origin of the Predominant Attractive Force at Work. Philosophical Transactions of the Royal Society B: Biological Sciences, 367, 3494-3502. http://www.ncbi.nlm.nih.gov/pmc/articles/PMC3497075/ http://dx.doi.org/10.1098/rstb.2012.0071

[31] Nobel, P.S. (2009) Physicochemical and Environmental Plant Physiology. 4th Edition, Academic Press, San Diego.

[32] Chen, L.S. and Nose, A. (2004) Day-Night Changes of Energy-Rich Compounds in Crassulacean Acid Metabolism (CAM) Species Utilizing Hexose and Starch. Annals of Botany, 94, 449-455. http://www.ncbi.nlm.nih.gov/pubmed/15277250 http://dx.doi.org/10.1093/aob/mch165

[33] Ceusters, J., Borland, A.M., Taybi, T., Frans, M., Godts, C. and De Proft, M.P. (2014) Light Quality Modulates Metabolic Synchronization over the Diel Phases of Crassulacean Acid Metabolism. Journal of Experimental Botany, 65, 3705-3714. http://www.ncbi.nlm.nih.gov/pubmed/24803500 http://dx.doi.org/10.1093/jxb/eru185

[34] Luttge, U. (2000) The Tonoplast Functioning as the Master Switch for Circadian Regulation of Crassulacean Acid Metabolism. Planta, 211, 761-769. http://www.ncbi.nlm.nih.gov/pubmed/11144260 http://dx.doi.org/10.1007/s004250000408

[35] Borland, A.M., Elliott, S., Patterson, S., Taybi, T., Cushman, J., Pater, B. and Barnes, J. (2006) Are the Metabolic Components of Crassulacean Acid Metabolism Up-Regulated in Response to an Increase in Oxidative Burden? Journal of Experimental Botany, 57, 319-328. http://www.ncbi.nlm.nih.gov/pubmed/16356942 http://dx.doi.org/10.1093/jxb/erj028 